\author{
B. Zoology \\ ISSN: $2090-0759$ \\ www.eajbs.eg.net
}

\title{
Updated description of Neolepidapedon (Neolepidapedon) macrum Overstreet, 1969 and Opisthomonorcheides decapteri Parukhin, 1966, infecting emperor fishes, Lethrinus nebulosus, in fish market of Abha city, Saudi Arabia
}

\author{
Abd El-Nasser-N. A. Hussein ${ }^{1}$; Dihom A. Al-Bassel ${ }^{2}$;Hoda Saady $^{1}$ and \\ Mohammed A. Al-Shehri ${ }^{3}$. \\ 1- Zoology Department, Faculty of Science-Qena, South Valley University, Egypt. \\ 2- Zoology Department, Faculty of Science, Fayoum University, Egypt. \\ 3-Biology Department, Faculty of Science, King Khalid University, Saudi Arabia. \\ E-Mail: abdelnasser@,1ycos.com
}

\section{ABSTRACT}

Emperor fishes, Lethrinus nebulosus are commercially important fishes in Saudi market. Despite of importance of these fishes, there is not a comprehensive report about parasitic fauna of these fishes. The aim of this research article is to determine the parasitic helminthes infecting these fishes in Saudi Arabia. For this purpose, 28 emperor fishes have been bought and examined by routine parasitological methods to find that $28.6 \%$ emperor fishes revealed intestinal trematode infections. Two trematodes were recognized in the fishes, Neolepidapedon (Neolepidapedon) macrum Overstreet, 1969 was found in 7 fishes (25\%) and Opisthomonorcheides decapteri Parukhin, 1966 was found infecting one fish only. Scanning electron microscope had shown absence of spines and revealed scale-like structure. Saudi Arabia is considered a new locality of those two trematodes and Emperor fishes as new hosts.

Key words: Commercial Red Sea fishes, trematodes, description, Saudi Arabia.

\section{INTRODUCTION}

Commercial fishes play an important role in spreading parasites and transmit them to the human beings. Many trematodes and larvae infect fishes and cause disease (Williams and Jones, 1994). Due to humans' increasing exploitation of the marine environment, the parasites are increasing in fishes. Sushi, natural seafood and other flesh fish dishes have been suspected of causing fishborne parasitic zoonoses (Deardorff, 1991). In Saudi Arabia, parasitological studies on fishes have focused on fishes from Red Sea and fish farms. However, studies on parasites from the commercially important fishes are still very few.

According to the available literature, Floriceps saccatus cestode belongs to order Trypanorhyncha had been described infecting the roving grouper fish (Plectropomus maculatus) from Red Sea (Banaja and Roshdy, 1979; Banaja et al., 1979). The same parasites has also recorded in Red Sea mackerel fish, Scomber japonicus collected and investigated in Jeddah by Banaja and Roshdy (1981). AbdelAal, et al., 1985 descried two new species of Lepidapedon trematodes of fishes from the Red Sea.

In Jeddah, Saudi Arabia, a cestode parasite, F. saccatus was found infecting the Red Sea grouper fish, P. maculatus, with infection rate of 58\% (Al-Jahdali, 2004).

The larval stages of this parasite lives in the abdominal cavity, consuming the infected fish by the parasite transferred to adult stages in the fish intestine. Abu- 
Zinada (1998) has been described cestode parasite (Grillotia sp.) parasitizing intestine of Red Sea grouper fish, P. maculatus. Also, Otobethrium cestode species has collected from mesenteries of emperor fish, L. mahsena.

The larval stages of $F$. saccatus had been found infecting many other Red Sea fish hosts, Egypt (Abdou, 2000, 2001, 2005).

Hassan et al. (2002) reported the occurrence of trypanorhynch cestodes in the flesh of marine fish from wholesale market. These were imported to Saudi Arabia from different countries along the Arabian Gulf. They stated that the highest intensity of plerocercoid was 45 per fish. Also it was observed that the infestation rate increased with fish size.

The postlarva of the cestode, Tentacularia bicolor have been collected from marine fish Dicentrarchus punctatus from Al-Qattif province of Saudi Arabia. The surface morphology of these post larvae have been studied (Al-Bassel, 2004).

A 38-year-old male Saudi patient was found infected with Diphyllobothrium latum in King Khalid University Hospital. The man is infected with D. latum through digestion raw or undercooked infected fish. This was the first case of this cestode to be reported in Saudi Arabia (Alkhalifa et al., 2006).

Nematodes larvae belonging to Eustrongylides parasitizing the liver of the Blenny Fish Alticus kirkii were studied (Al-Jahdali, 2007).

In Saudi Arabia, for the first time, Hussein et al. (2011) reported Karyakartia egyptensis trematode infecting grouper fish (Epinephelus coioides) and Neolepidapedon polyprioni trematode parasitizing emperor fishes (Lethrinus nebulosus). Also, larval stage of the cestode Floriceps saccatus was found infecting grouper fish.

In Yamen, for the first time, the presence of the larval stages of a trypanorhynch infecting the commercial fish L. lentjan has been recorded by Al-Zubaidy (2006). The infection rate was $26.6 \%$. In the same study the author described other larval stages belong to Trypanorhyncha.

Despite the recent increase in raw fish foods, the people are unaware of the risk of infection associated with eating exotic ethnic dishes. So, the objective of the present study is to describe and to expand our knowledge of two intestinal trematodes parasitizing emperor fishes, L. nebulosus, a commercial red sea fish bought from fish market in Abha city, Saudi Arabia.

\section{MATERIALS AND METHODS}

Asir is a wide region of Saudi Arabia located in the southwest of the country. The region is constituted of twelve governorates. It has an area of $81,000 \mathrm{~km}^{2}$ and an estimated population of 1,563,000. It shares a short border with Yemen. Geographically, the Aseer region is situated on a high plateau that receives more rainfall than the rest of the country. Aseer is the country of many farmers. It contains the country's highest altitudes, which rise to almost 3,000 metres near Abha (http://en.wikipedia.org/wiki/'Asir_Province).

The economical important emperor fish, L. nebulosus, had been bought regularly from fish markets in Abha city. These fishes were captured from the Red Sea coastal water of Jazan province in the Southwest of Saudi Arabia. The fishes were bought and examined for helminthes parasitic infection. Fishes have conducted immediately to identification according to a global information system site by Froese and Pauly (2009) and World Register of Marine Species (WoRMS) by Appeltans et al. (2009). The length of the emperor fish ranged between 15 and $25 \mathrm{~cm}$. 
The fishes had been dissected, the intestine was removed and its content was investigated using a dissecting microscope. The helminthe parasites have been recovered.

The flattened specimens were fixed in 5\% neutral formalin. Staining has been done using Kirk Patrick's carmalum staining method. After complete dehydration, clearing was carried out in clove oil and the specimens were mounted in Canada balsam. Fixation and staining was done according to Drury and Wallington (1980).

For scanning electron microscope, the fresh specimens of $N$. (N.) macrum were fixed in phosphate buffered 5\% gluteraldehyde (PH 7.4), then post-fixed in 1\% osmium tetraoxide. The specimens were washed in Na-phosphate buffer (PH 7.4), then processed in drying apparatus, subsequently mounted on copper studs and gold coated. The smears had been examined using JEOL JSM-T5 kV scanning electron microscope.

\section{RESULTS}

Examination of 28 emperor fish, L. nebulosus revealed prevalence of infections of 8 fishes $(28.6 \%)$ N. (N.) macrum Overstreet, 1969 was found in 7 fishes (25\%) and O. decapteri Parukhin, 1966 was found infecting one fish only.

1- N. (N.) macrum Overstreet, 1969 (Family: Lepocreadiidae, Odhner 1905) (Figs. 1 and 2)

$N$. (N.) macrum Overstreet, 1969 has been found parasitizing the intestine of emperor fish, L. nebulosus. Also the immature stage has been reported (Fig. 1).

\section{Description:}

Immature stage is characterized by the general characters of the genus. Also, the excretory vesicle is extending almost to the intestinal bifurcation. Also, the accumulation of wastes was noticed at the posterior end as a product of voracious feeding of the larva.

Description is based on seven specimens (Fig. 2). There are structures that appear to be spine-like scales at the anterior part of the body tegument, which gradually disappear to the middle and posterior ends. The adult flattened fluke measured $7.29 \pm 1.11 \mathrm{~mm}$ by $1.89 \pm 0.23 \mathrm{~mm}$ in length and width, respectively. The anterior part of the body was narrow while the middle part was more flattened. Oral sucker (long $211.43 \pm 9 \mu \mathrm{m}$ ) is slightly larger than the ventral sucker (long $182.86 \pm 9.51 \mu \mathrm{m})$. The prepharynx is very short $(9.43 \pm 0.79 \mu \mathrm{m})$, followed by short thick wall pharynx measured $100.86 \pm 4.49 \mu \mathrm{m}$. The oesophagus is long and measured $197.14 \pm 4.88 \mu \mathrm{m}$. The bifurcation of the intestinal caeca arises far from the ventral sucker and the distance between bifurcation and ventral sucker is $748.57 \pm 6.9 \mu \mathrm{m}$. The ovary is submedian, slightly rounded and measured $198.57 \pm 6.90 \mu \mathrm{m}$. The testes are smooth rounded and tandem in position, the first one measured $471.43 \pm 6.9 \mu \mathrm{m}$ and the other one measured $475.71 \pm 7.87 \mu \mathrm{m}$. The distance between the testes is $247.14 \pm 9.51 \mu \mathrm{m}$. The intestinal caeca is extending almost to posterior end of the body.

Scanning electron microscopic studies of $N$. (N.) macrum Overstreet, 1969 showed absence of spines around the suckers and over the body. The anterior sucker has frontal position and the genital atrium is much closer to the posterior sucker, which is pedunclated. This investigation has shown the presence of scale-like structure all over the body but more clearly around the posterior sucker (Figs. 4, 5 and $6)$. 
2- O. decapteri Parukhin, 1966 (Family: Monorchiidae, Odhner, 1911) (Fig. 3) O. decapteri Parukhin, 1966, flukes were found parasitizing the intestine of one emperor fish, L. nebulosus.

\section{Description:}

Description based on one specimen. The fluke has an elongated and flattened body. It has rounded ends body and measured $1.2 \mathrm{~mm}$ in length. Oral and ventral suckers are nearly equal in size ( 80 and $90 \mu \mathrm{m}$ in diameter). The prepharynx measured $200 \mu \mathrm{m}$, followed by short thick wall pharynx $(80 \mu \mathrm{m})$ and then oesophagus with a length of $120 \mu \mathrm{m}$. The intestinal caeca arise nearer to ventral sucker. The distance between bifurcation and ventral sucker is $90 \mu \mathrm{m}$. Due to crowded eggs in the posterior part, it is difficult to identify and measure the ovary. There is only one testis measured $150 \mu \mathrm{m}$.

\section{DISCUSSION}

Larval stages of $F$. saccatus have been recorded many times in different marine fishes in Saudi Arabia (Banaja and Roshdy, 1979; Banaja et al., 1979; AlJahdali, 2004; Banaja and Roshdy, 1981). Two new species of Lepidapedon trematodes have been described parasitizing Red Sea fishes (Abdel-Aal et al., 1985).

$N$. (N.) macrum, was described, based on one specimen, by Overstreet (1969) as a new species from the intestine of marine fish Mycteroperca microlepis from Biscayne Bay, Florida. This genus was established by Manter (1954) as N. polyprioni from Polyprion oxygeneios fish from Portobello. Yamaguti (1971) outlined this species belonging to the subgenus Neolepidapedon as the type species $N$. polyprioni Manter, 1954 and listed 7 species. Since Manter (1954) created the genus Neolepidapedon, about 23 species have been descried (http://www.organismnames.com). The last species descried is Neolepidapedon opisthobifurcatus by Zdzitowiecki (1990). Examination of $N$. (N.) macrum Overstreet, 1969 using Scanning electron microscope (SEM) had been shown the structure named scale-like structure. Those structures are scattered over the body but concentrated at the fore part of the body especially around the posterior sucker. Those structures have been shown using light microscope and described as spines but using SEM clarifies the appearance of those structures. The structure appeared as scales, so they named scale-like structure. The later appeared to have a peduncle.

In Saudi Arabia, for the first time, Hussein et al. (2011) described N. polyprioni parasitizing emperor fishes (L. nebulosus). The present species differs from $N$. polyprioni in much longer body size; smaller suckers sizes; shorter pharynx; longer Distance between bifurcation and ventral sucker and slightly bigger testes sizes. There are no eyespot pigments in the present species, while they are present in $N$. macrum, Overstreet, 1969. Saudi Arabia is considered a new locality of this parasite and emperor fish (L. nebulosus) a new host.

The genus Opisthomonorcheides has been established by Parukhin (1966) for the new species O. decapteri. Yamaguti (1971) has outlined O. decapteri. Ahmed (1976) described $O$. indicus as a new species that was collected from the intestine of the fish Apogonichthys ellioti (Day), from the Bay of Bengal, off the Puri coast, Orissa, India. Since that date, no other species was described. The present study updates the description of $O$. decapteri. Since the description of the genus Opisthomonorcheides by Parukhin (1966), 21 species have been descried (http://www.organismnames.com). The last species descried was O. yamagutinsis by Lokhande (1993). 


\section{REFERENCES}

Abdel AAL, T. M., Banaja, A.A. and Al-Zanbagi, N. A. (1985): Trematodes of fishes from the Red Sea. Two new species of Lepidapedon strafford, 1904. J. Egypt. Soc. Parasit., 15(1): 165-170.

Abdou, N. E. (2000): Light and scanning electron microscopy of Floriceps sp. Plerocercoid (Cestoda: Trypanorhyncha) from the Red Sea fish Tylsums choram. J. Union Arab. Biol., 14(A) Zool.: 37-47.

Abdou, N. E. (2001): A record of Floriceps sp. plerocercoid larvae (Trypanorhyncha) from the Red Sea fish Euthynnus afinis with scanning electron microscopy. J. Egypt. Ger. Soc. Zool., 35(D): 29-38.

Abdou, N. E. (2005): Scanning electron microscopy of the plerocercoid Floriceps minacanthus (Cestoda: Trypanorhyncha) parasitize the fish Cephalopholis micri, A new host record in the Red Sea, Egypt. J. Egypt. Ger. Soc. Zool., 47(D), 133-145.

Abu-Zinada, N. (1998): Observations on two larval cestodes from Red Sea fishes at Jeddah, Saudi Arabia. Vet. Med. J. Giza, 46(2): 193-197.

Ahmed, J. (1976): Two New Species of Digenetic Trematodes of Fishes from the Bay of Bengal. Netherlands Journal of Zoology, 27(3): 305-309.

Al-Bassel, D. A. H. (2004): Surface ultrastructure of the scolex of the postlarva of Tentacularia bicolar (Cestoda: Trypanorhyncha). J. Egypt. Ger. Soc. Zool., 44 (D): 53-67.

Al-Jahdali, M. O. (2004): The prevalence and sites of infection of the tape worm larval stages Floriceps saccatus (Trypanorhyncha), in the Red Sea grouper fish Plectropomus maculatus with comments on its life cycle and systematics. Journal of Jeddah Teacher's College, 2: 58-76.

Al-Jahdali, M. O. (2007): Infection of the liver of the blenny Fish Alticus kirkii by eustrongylides larvae (Nematode: Anisakidae), identification and histopathological observations. Journal of Jeddah Teacher's College, 1: 22-29.

Al-Khalifa, I. S.; Hassan, R. R; Abdel-Hameed, A. A.; Al-Khayal, L. A. (2006): Diphyllobotheriasis in Saudi Arabia. Saudi Med. J., 27(12): 1901-1904.

Al-Zubaidy, A. B. (2006): First record in Yemen of two larval trypanorhynch cestodes in commercial fish (Lethrinus lentjan) from the Red Sea. JKAU: Mar. Sci., 17: 79-87.

Appeltans, W; Bouchet, P.; Boxshall, G. A.; Fauchald, K.; Gordon, D. P.; Hoeksema, B. W.; Poore, G. C. B.; Van Soest, R. W. M.; Stoehr, S.; Walter, T. C. and Costello, M. J. (EDS) (2009): World Register of Marine Species. Accessed at http://www.marinespecies.org on [2010-October].

Banaja, A. A. and Roshdy, M. A. (1979): Scanning electron microscopy of the scolex of a trypanorhynch plerocercus in the fish, Plectropomus maculatus (Bloch) (Cestoda: Trypanorhynch). Bull. Fac. Sci., K.A.U., Jeddah, 3: 29-35.

Banaja, A. A. and Roshdy, M. A. (1981): Observations by light and scanning electron microscopy on larval stages and a pterobothriid trypanorhynch cestode in the mackerel fish, Scomber japonicus from Red Sea. Bull. Fac. Sci., K.A.U., Jeddah, 5: 69-75.

Banaja, A. A.; Roshdy, M. A.; Ghandour, A. M. and Farag, A. A. (1979): Observations on larval stages of a trypanorhynch cestode in the fish, Plectropomus maculatus (Bloch) from the Red Sea. Bull. Fac. Sci., K.A.U., 3: 9-18. 
Deardorff, T. L. (1991): Epidemiology of marine fish-borne parasitic zoonoses. Southeast Asian J. Trop. Med. Public. Health., 22(1): 146-149.

Drury, R. A. B. and Wallingten, E. A. (1980): Carleton's Histological Technique. $5^{\text {th }}$ Ed. Oxford University Press.

Froese, R. and Pauly, D. (EDITORS) (2009): FishBase. World Wide Web electronic publication. www.fishbase.org, version (10/2009).

Hassan, M. A.; Palm, H. W.; Mahmoud, M. A. and Jama, F. A. (2002): Trypanorhynch cestodes from the musculature of commercial fishes from the Arabian Gulf. Arab Gulf Journal of Scientific Research, 20(2): 74-86.

Hussein, A. N. A.; Bin-Dajem, S. M., Rabie, S.A.H. and Mubarki, H.A.Y. (2011): Intestinal helminthes infecting some commercial red sea fishes in Abha city, Saudi Arabia. J. Egypt. Ger. Soc. Zool., 62 (D): 9-17.

Lokhande, L. U. (1993): Opisthomonorcheides yamagutinsis sp. nov. from the intestine of pomfret Stromateus argenteus. Journal of the Marine Biological Association of India, 35(1-2): 229-232.

Manter, H. W. (1954): Some digenetic trematodes from fishes of New Zealand. Trans. Roy. Soc. N. Z. Zool., 82(2): 475-568.

Overstreet, R. M. (1969): Digenetic trematodes of marine teleost fishes from Biscayne Bay, Florida. Tulane studies in Zoology and Botany; 15(4): 119-175.

Parukhin, A. M. (1966): On species of the helminth fauna of fishes in the South Atlantic. Materialy Nauchnoi Konferentsii Vsesoyuznogo Obshchestca Gel'mintologov 3: 219-222. (In Russian).

Williams, H. and Jones, A. (1994): Parasitic worms of fishes. Taylor and Francis Ltd. U. K.

Yamaguti, S. (1971): Synopsis of Digenetic Trematodes of Vertebrates. Tokyo, Keigaku. Publ 1074.

Zdzitowiecki, K. (1990): Little known and new Antarctic Digenea species of the genera Neolepidapedon and Lepidapedon (Lepocreadiidae). Acta Parasitologica Polonica, 35: 19-30. 


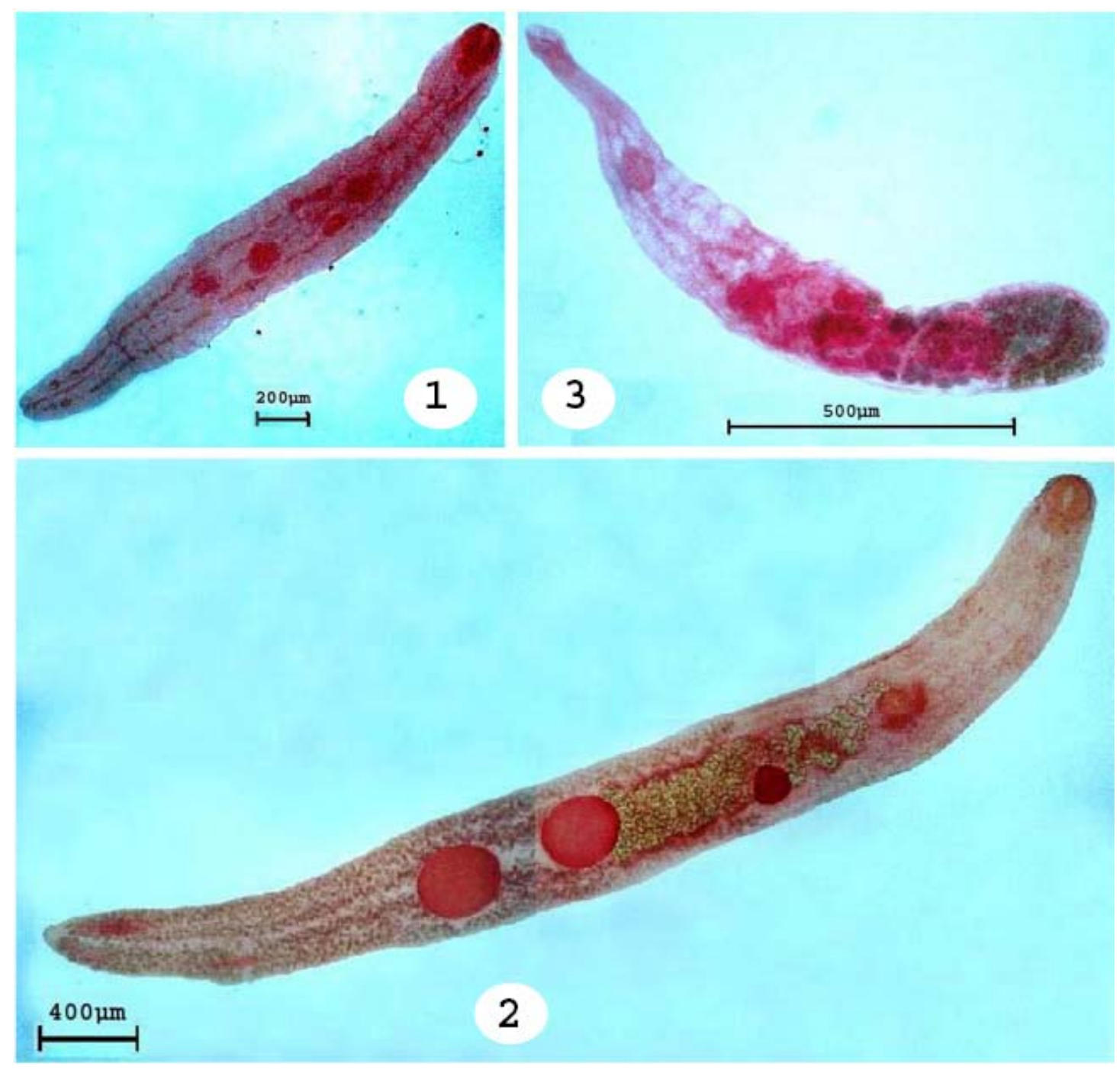

Fig. 1: Photomicrograph of immature stage of Neolepidapedon (Neolepidapedon) macrum from emperor fishs, Lethrinus nebulosus.

Fig. 2: Photomicrograph of mature stage of Neolepidapedon (Neolepidapedon) macrum from emperor fishs, Lethrinus nebulosus.

Fig. 3: Photomicrograph of mature stage of Opisthomonorcheides decapteri from emperor fishs, Lethrinus nebulosus. 

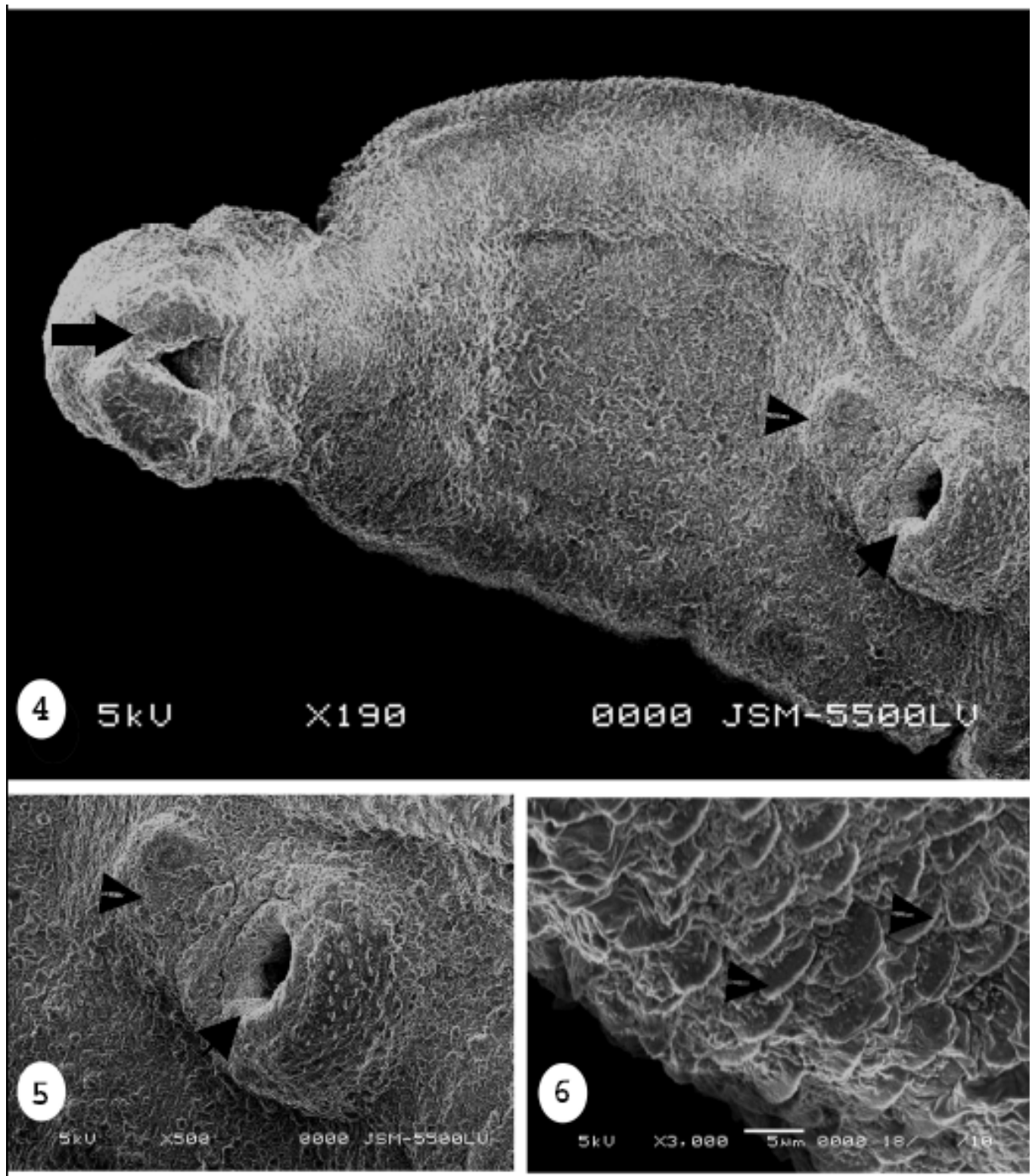

Fig. 4: Scanning electron micrograph of mature stage of Neolepidapedon (Neolepidapedon) macrum, showing the anterior part of the body and the anterior position of the anterior sucker. X 190

Fig. 5: Scanning electron micrograph of mature stage of Neolepidapedon (Neolepidapedon) macrum, showing the posterior sucker armed with scale-like structure, also showing the genital atrium. X 500

Fig. 6: Scanning electron micrograph of mature stage of Neolepidapedon (Neolepidapedon) macrum, showing the scale-like structures. X 3.000 


\section{ARABIC SUMMARY}

تحديث وصف Neolepidapedon (Neolepidapedon) macrum Overstreet, 1969 و

Lethrinus ، Opisthomonorcheides decapteri Parukhin, 1966 nebulosus

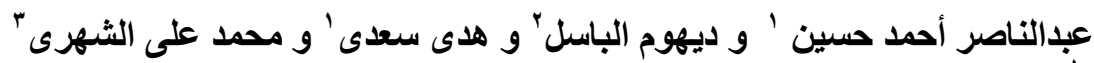

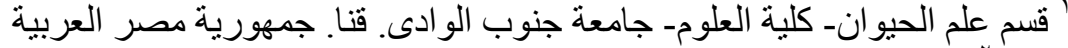

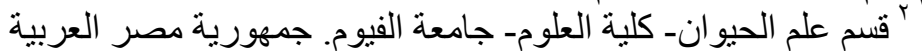

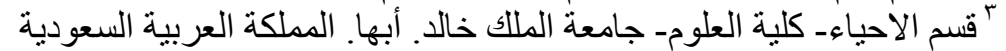

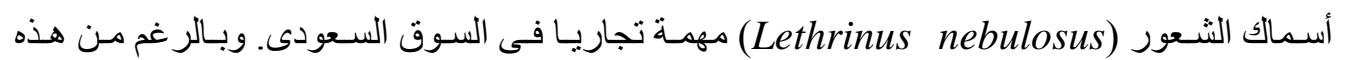

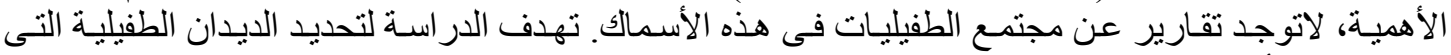

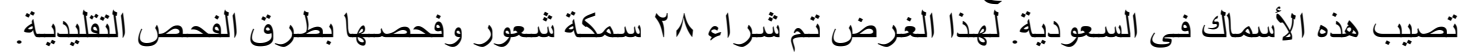

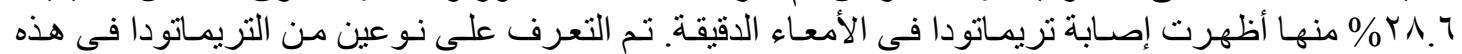
الأسماك، حيث أن

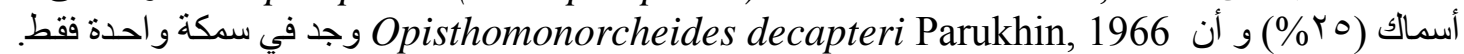

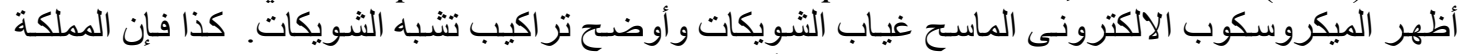
العربية السعودية تعتبر بيئة جديدة لهذه التريماتودا، وأن اسماك الثعور الثابك عائل جديد لها. 